\title{
Imaging for the diagnosis and response assessment of renal tumours
}

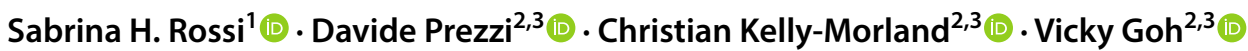

Received: 2 April 2018 / Accepted: 15 May 2018 / Published online: 13 June 2018

(c) The Author(s) 2018

\begin{abstract}
Purpose Imaging plays a key role throughout the renal cell carcinoma (RCC) patient pathway, from diagnosis and staging of the disease, to the assessment of response to therapy. This review aims to summarise current knowledge with regard to imaging in the RCC patient pathway, highlighting recent advances and challenges.

Methods A literature review was performed using Medline. Particular focus was paid to RCC imaging in the diagnosis, staging and response assessment following therapy.

Results Characterisation of small renal masses (SRM) remains a diagnostic conundrum. Contrast-enhanced ultrasound (CEUS) has been increasingly applied in this field, as have emerging technologies such as multiparametric MRI, radiomics and molecular imaging with ${ }^{99 \mathrm{~m}}$ technetium-sestamibi single photon emission computed tomography/CT. CT remains the first-line modality for staging of locoregional and suspected metastatic disease. Although the staging accuracy of CT is good, limitations in determining nodal status persist. Response assessment following ablative therapies remains challenging, as reduction in tumour size may not occur. The pattern of enhancement on CT may be a more reliable indicator of treatment success. CEUS may also have a role in monitoring response following ablation. Response assessments following anti-angiogenic and immunotherapies in advanced RCC is an evolving field, with a number of alternative response criteria being proposed. Tumour response patterns may vary between different immunotherapy agents and tumour types; thus, future response criteria modifications may be inevitable.
\end{abstract}

Conclusion The diagnosis and characterisation of SRM and response assessment following targeted therapy for advanced $\mathrm{RCC}$ are key challenges which warrant further research.

Keywords Renal cancer $\cdot$ Imaging $\cdot$ Diagnosis $\cdot$ Staging $\cdot$ Treatment response

\section{Introduction}

Over 337,000 new cases of renal cell carcinoma (RCC) are diagnosed annually worldwide [1]. In Western European countries such as the UK, the majority of renal cancers are early of stage (stage I-II: 56\%), as a result of the rising incidence of incidentally detected tumours with the increased use of cross-sectional imaging [2, 3]. Characterisation of

Vicky Goh

vicky.goh@kcl.ac.uk

1 Academic Urology Group, University of Cambridge, Addenbrooke's Hospital, Cambridge Biomedical Campus, Cambridge CB2 0QQ, UK

2 Cancer Imaging, School of Biomedical Engineering \& Imaging Sciences, King's College London, London, UK

3 Department of Radiology, Guy's \& St Thomas' NHS Foundation Trust, London SE1 7EH, UK incidental renal lesions remains a diagnostic challenge, particularly for small renal masses ( $\mathrm{SRM},<4 \mathrm{~cm}$ in size) and in differentiating malignancy from oncocytoma and fat-poor angiomyolipoma. Accurate diagnosis of incidental SRM has life-changing consequences for patients as well as economic implications [4]. Accurate staging of RCC and radiologic assessment of response to therapy are crucial to guide management and to deliver realistic information regarding treatment and prognosis to patients [5]. Imaging plays a key role throughout the RCC patient pathway, from diagnosis and staging of the disease, to the assessment of response to therapy. This review aims at summarising current knowledge regarding imaging as applied to the RCC patient pathway, highlighting advances and focusing on key challenges to guide further research. We therefore summarise current and emerging evidence regarding imaging for the diagnosis, staging and response assessment of renal cancer. 


\section{Methods}

A non-systematic literature search was conducted using Medline, updated to December 2017. For each of the sub-sections of the manuscript (diagnosis, staging and response assessment), a separate literature search was performed, using combinations of the following key words and medical subject headings: RCC, kidney cancer, renal carcinoma, renal cancer, small renal mass, Bosniak cyst, diagnosis, staging, response, ablation and metastatic. Each of the imaging modalities was also investigated in turn. The search was limited to English language studies. The reference lists of selected manuscripts were checked manually for eligible articles. The most relevant articles summarising existing knowledge of imaging in renal cancer were selected for this review. In addition, key international guidelines were reviewed in urology, radiology and oncology, including the European Association of Urology (EAU), American Urological Association (AUA), Canadian Urological Association (CUA), European Society for Medical Oncology (ESMO), American College of Radiologists (ACR) and the Cardiovascular and Interventional Radiological Society of Europe (CIRSE) [5-11]. Key criteria for response assessment were also manually searched [12-18].

\section{Results}

\section{Diagnosis and characterisation}

\section{Symptomatic vs. asymptomatic patients}

Symptomatic patients typically present with more advanced RCC than patients with incidentally detected tumours $[19,20]$. The prevalence of RCC in patients presenting with visible haematuria is $0.9-2.0 \% ; 0.3-1.0 \%$ in patients with microscopic haematuria [21, 22]. Computed tomography (CT) urography is recommended as the most appropriate first-line test for patients presenting with unexplained visible haematuria by the AUA and the CUA $[9,10]$. However, there is a lack of consensus regarding the optimal investigation of asymptomatic microscopic haematuria in different guidelines worldwide in terms of imaging modality (ultrasound vs. CT urography) and age threshold to prompt investigation [23]. An ultrasound (US) of the renal tract may be considered initially in lowrisk young patients with non-visible haematuria as a costeffective non-ionising technique for assessing the kidneys and bladder [24, 25]. However, US sensitivity is low for renal lesions $<1 \mathrm{~cm}$ (26\%) [26] and it does not evaluate the collecting systems adequately; hence, CT urography (pre- and post-contrast) is recommended as a first-line tool for patients presenting with non-visible haematuria by a number of American associations [9, 11, 23, 27]. CT urography following contrast administration assesses the entire urinary tract [28] and has a better diagnostic yield for renal cancer than intravenous urography (IVU), with a sensitivity of $100 \%$, specificity of $97.4 \%$ and accuracy of $98.3 \%$ [29]. Magnetic resonance (MR) urography has the advantage of higher soft tissue contrast compared to $\mathrm{CT}$ and it has no radiation burden, but is prone to motion artefacts and limited by MR contraindications and scanner availability [30]. MR urography may be reserved for problem-solving, in pregnancy or when patients have an iodinated contrast allergy or renal failure.

Up to $50 \%$ of new cases of renal cancer will be detected incidentally in asymptomatic patients undergoing imaging for an unrelated indication [31]. In fact, over $40 \%$ of Medicare insurance beneficiaries in the USA undergo CT of the chest and abdomen over a 5-year period [32]. In a study of 3001 adults undergoing CT colonography, $14.4 \%$ of patients had at least one renal mass $>1 \mathrm{~cm}$ [33]. However, characterisation of incidentally detected small renal tumours remains a major challenge for imaging.

\section{Cystic masses}

The Bosniak classification is a well-established system to classify renal cysts based on CT findings [34]. Risk of malignancy is predicted based on the appearance of the cyst wall, number and thickness of septations, calcification and enhancement (Fig. 1) [35]. Simple cysts do not enhance following contrast administration; however CT pseudoenhancement may occur, where simple cysts appear to demonstrate enhancement $<20$ Hounsfield units (HU) due to the CT reconstruction algorithm [36]. Two recent meta-analyses have demonstrated malignancy rates $<6 \%$ in Bosniak II to IIF cysts, with rates of over 50\% in Bosniak III and approximately $90 \%$ in Bosniak IV lesions [35, 37]. EAU guidelines recommend surveillance for Bosniak IIF cysts and operative management for patients with Bosniak III-IV cysts, and therefore differentiating category IIF and III lesions is crucial [5]. However, considerable inter-observer disagreement has been noted in differentiating IIF and III cysts [37]. The effectiveness of the Bosniak classification system for category III cysts has been shown to be suboptimal, leading to considerable operative overtreatment in patients who are found to have benign disease (Fig. 2) [37]. Pitra et al. suggest that MRI may be used for reclassification of Bosniak IIF and III cysts, leading to significant changes in operative management in over a third of cases [38]. Magnetic resonance imaging has superior soft tissue contrast resolution compared to CT, potentially resulting in exaggerated septal 


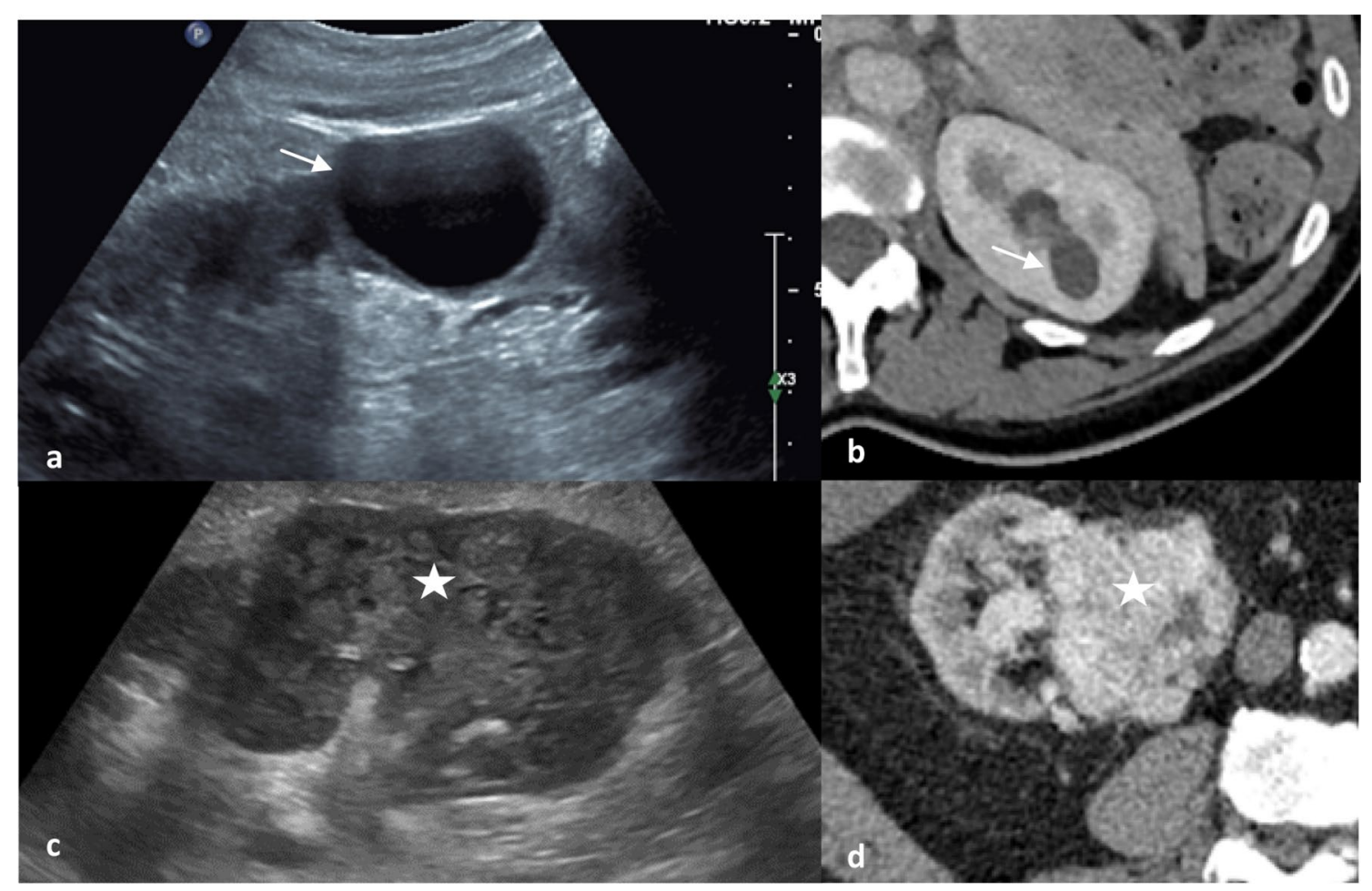

Fig. 1 Ultrasound (a) and CT (b) appearances of a simple cyst with a thin imperceptible wall and posterior acoustic enhancement and no internal echoes or enhancement (Bosniak I). Contrast this to the ultrasound (c) and CT (d) features of a clear cell renal cell carcinoma with ill-defined borders and solid mixed echogenicity replacing renal parenchyma and avid contrast enhancement with areas of low attenuation tumoral necrosis on CT

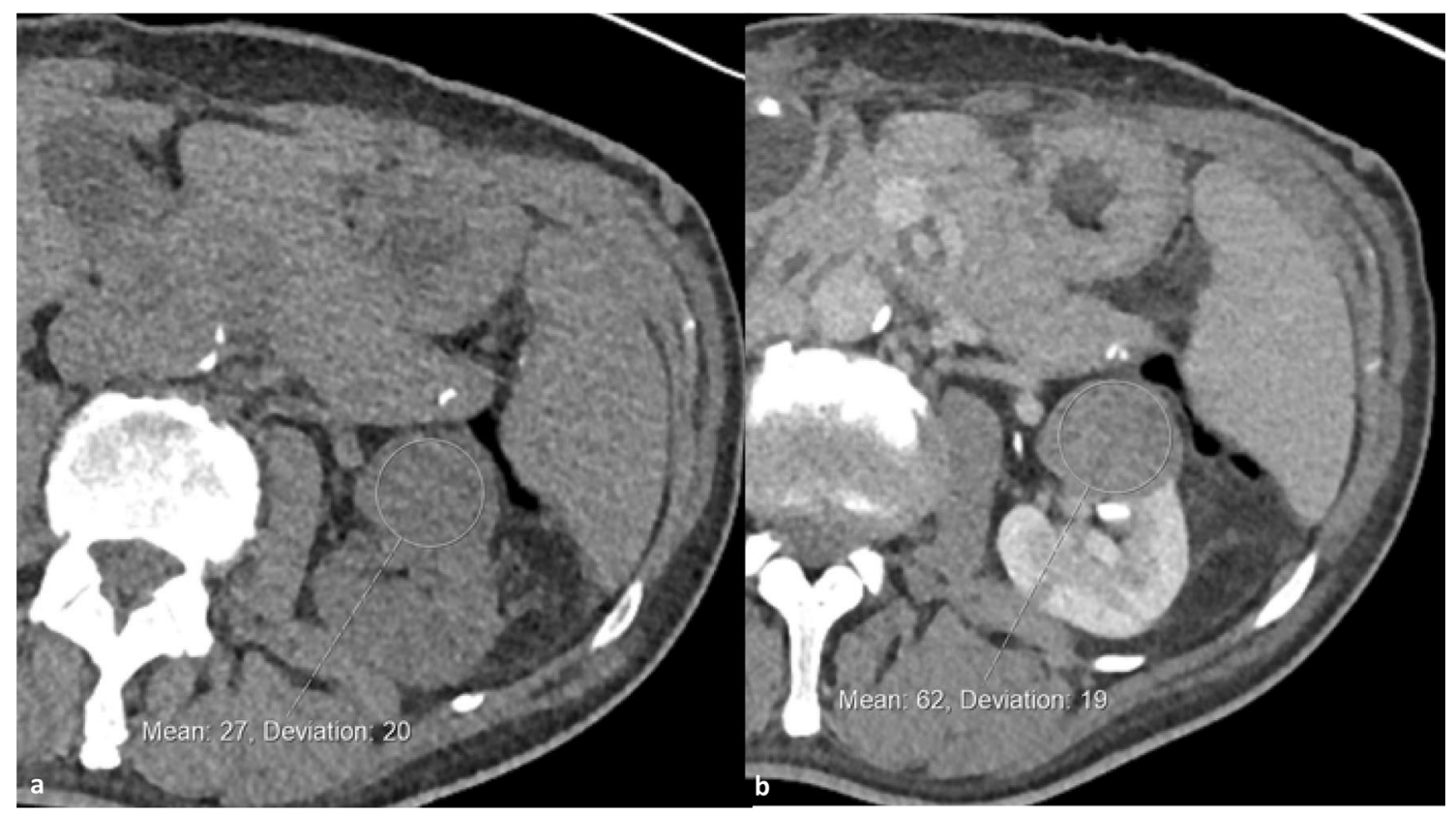

Fig. 2 Non-enhanced (a) and split-bolus post-contrast nephrographic/ urographic phase images (b) with a circular region of interest centred on a $3 \mathrm{~cm}$ left interpolar low attenuation renal mass demonstrating definite internal enhancement (Hounsfield units increasing from 27 to 62). This was confirmed as a type 1 papillary renal cell carcinoma 
thickness and more prominent septal enhancement, and may also upgrade the Bosniak classification in small $(<2.5 \mathrm{~cm})$ cysts [39]. MRI also allows improved visualisation of haemorrhagic cysts, typically hyperintense on T1-weighted sequences, compared to CT [39]. Contrast-enhanced ultrasound (CEUS), involving encapsulated microbubbles of gas injected intravenously as contrast agent has shown to be as effective as CT for renal cyst classification with the Bosniak system [40], and even superior to CT for the detection of malignancy in complex renal cysts [41]. Additionally, CEUS has also been found to have a higher sensitivity and specificity compared to MRI for the differentiation of complex renal cysts and malignancies [42].

\section{Solid masses}

Few imaging features are discriminatory in the diagnosis of solid renal masses and approximately $20 \%$ of lesions removed at surgery will be benign as a consequence [43]. There is an increasing likelihood of malignancy and higher grade with increasing lesion size [34, 44, 45]. Of benign SRM that are surgically excised, $10-38 \%$ are found to be angiomyolipomas and $34-58 \%$ are found to be oncocytomas [46-48]. Ultrasound, contrast-enhanced CT and MRI may aid diagnosis (Table 1). The presence of enhancement, i.e. a change of $\geq 15 \mathrm{HU}$ before and after contrast administration in CT, is considered the most important criterion for the differentiation of malignant solid SRM subtypes, with clear cell RCC enhancing much more compared to chromophobe and papillary RCC [5, 49]. However, reliable differentiation between RCC and oncocytoma and fat-poor angiomyolipoma remains a challenge.

Angiomyolipoma (AML), the most common benign renal tumour, is in most cases characterised by the presence of macroscopic fat (Fig. 3). Therefore, AMLs appear markedly hyperechoic on ultrasound and typically there is low attenuation ( -10 to $-100 \mathrm{HU}$ ) on unenhanced CT. On MRI, signal drop on fat-suppressed and opposed-phase T1 sequences is thought to be typical $[50,51]$. Some RCCs may contain fat; however, and the presence of calcifications may point towards a diagnosis of malignancy [52]. AMLs may contain minimal fat in approximately $5 \%$ of cases and therefore may be difficult to differentiate from RCC. Fat-poor AMLs demonstrate marginally higher attenuation on unenhanced CT than RCC [52]. The combination of homogeneous enhancement and prolonged enhancement pattern on CT resulted in a positive predictive value of $91 \%$ and negative predictive value of $87 \%$ for the differentiation of fat-poor AML and RCC [50]. A meta-analysis has demonstrated a pooled sensitivity of 0.67 (95\% CI $0.48-0.81$ ) and specificity of 0.97 (95\% CI $0.89-0.99$ ) for the ability of CT to diagnose fat-poor AML [53].

Differentiating oncocytomas, the second most common benign tumour type, from RCC remains a diagnostic challenge both on imaging and renal biopsy. As a result, oncocytoma is found on 3-4\% of nephrectomy pathology specimens [54]. In fact, whilst the positive predictive value of diagnosing malignancy on renal biopsy is $>99 \%$, one in four renal biopsies reported as oncocytoma are found to be RCC following surgical excision [55]. On ultrasound, oncocytomas

Table 1 Rationale underlying the use of common imaging modalities in the characterisation of small renal masses

\begin{tabular}{ll}
\hline Imaging Modality & Comments \\
\hline Ultrasound & User dependent \\
& Sensitivity is low for small renal lesion [26, 101] \\
& Doppler may demonstrate vascularity in the periphery of the mass, suggestive of oncocytoma \\
& No radiation, therefore ideal for repeated scanning and surveillance \\
& Does not evaluate the collecting system adequately [26] \\
& Gold standard of imaging; however, poor differentiation between solid masses, fat-poor AML and oncocytoma \\
& Enables assessment of contrast enhancement and presence of fat, two key diagnostic features [5, 49]. \\
Contrast enhanced CT & Presence of central stellate scar and segmental enhancement inversion is suggestive of oncocytoma \\
& Gain additional information including morphology of contralateral kidney and surgical characteristics in \\
& patients in whom surgical excision is considered \\
& Superior soft tissue contrast resolution compared to CT \\
& May upgrade the Bosniak classification in small cysts and allows improved visualisation of haemorrhagic cysts \\
& Enables characterisation of solid renal masses \\
& No radiation burden \\
MRI & Prone to motion artefacts \\
& Limited by MR contraindications, scanner availability and cost \\
& Useful for problem-solving, in pregnancy or when patients have an iodinated contrast allergy or renal failure \\
& Involves microbubbles of gas injected intravenously as contrast agent, therefore enabling detection of slow and \\
low flow in the microcirculation \\
Requires a trained operator \\
May be used for reclassification of Bosniak IIF and III cysts and to characterise solid renal masses [5]
\end{tabular}




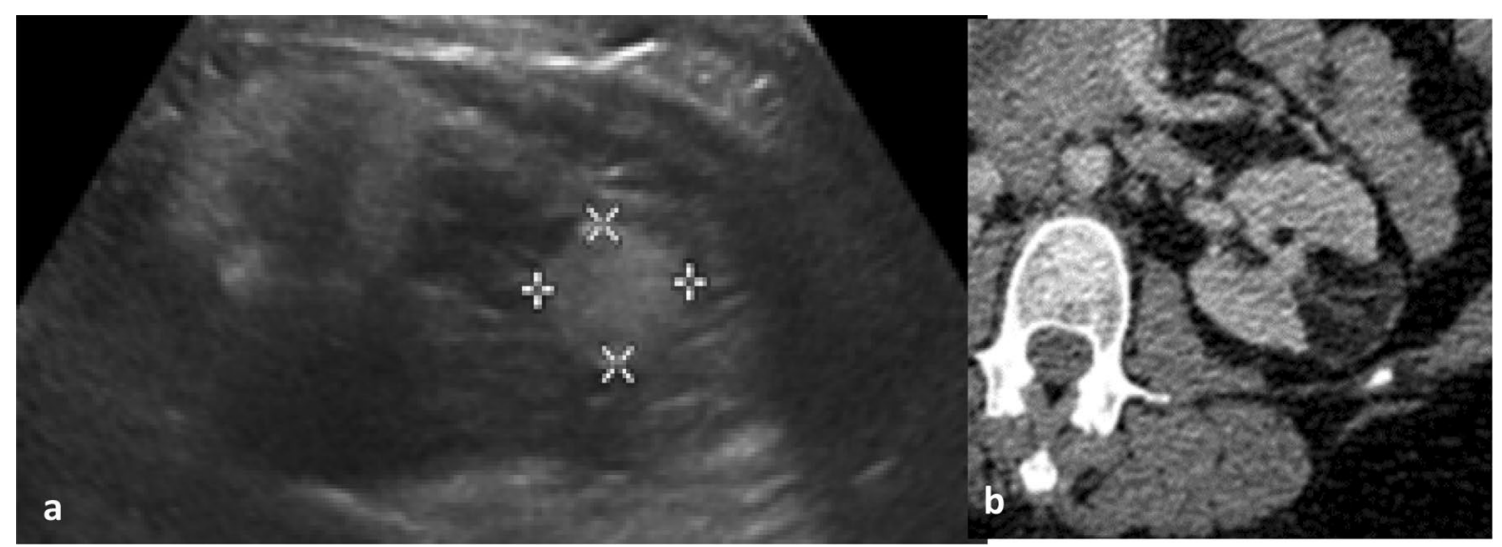

Fig. 3 Classical ultrasound (a) and CT (b) appearances of a left renal angiomyolipoma. Solid hyperechoic mass relative to renal parenchyma and of fat attenuation on CT with enhancing components

classically appear as well-circumscribed, homogeneous masses which may be isoechoic or hypoechoic. Oncocytomas are well vascularised; therefore, Doppler ultrasound may show increased vascularity in the periphery of the mass. On CT, these benign tumours often display homogeneous enhancement, and in the absence of calcification, necrosis and haemorrhage [56]. Oncocytomas may display a characteristic central stellate scar in up to one-third of cases, although this may be less evident in smaller lesions [57]. Chromophobe RCCs may contain a central scar, whilst other RCC subtypes that contain central necrosis may be confused for a stellate scar [58]. Segmental enhancement inversion, a tumour segment with lower signal intensity in the arterial phase and higher intensity at the early excretory phase, is considered suggestive of oncocytomas: with a high specificity $(87-100 \%)$, but discrepancies in reported sensitivity [57-59].

In one study of biopsy-confirmed renal tumours, CT growth pattern, interface with the parenchyma, presence of a scar, segmental inversion of enhancement, unenhanced CT histogram and pattern of enhancement on triphasic MDCT were studied [49]. This study found that only gradual enhancement was suggestive of a benign pathology; however, it is well known that benign lesions also demonstrate early rapid enhancement, confounding interpretation [60]. For example, benign oncocytomas and malignant clear cell renal cancer share enhancement characteristics due to the dense vascularisation of oncocytomas.

Multiparametric MRI has the potential to improve the characterisation of solid renal tumours, but its diagnostic accuracy and cost-effectiveness are yet to be investigated prospectively [61, 62]. Retrospective studies have used it to differentiate small renal masses that demonstrate a high signal intensity central area on T2-weighted imaging, which may represent either oncocytoma with a central scar or RCC with central necrosis. Complete late enhancement of the central area on gadolinium-enhanced T1-weighted images, typical of fibrosis, was suggestive of oncocytoma, whereas absence of central enhancement (typical of necrosis) or presence of a signal drop on chemical shift imaging (in keeping with the presence of intracellular fat) were used to rule out oncocytoma, as it does not contain either [58]. Galmiche et al. suggest that multiparametric MRI may distinguish between oncocytoma and chromophobe RCC based on enhancement and diffusion characteristics [63]. In a study by Taouli et al., contrast-enhanced MRI performed better than diffusion MRI in differentiating between solid RCC and benign tumours (when excluding fat-rich AML), with a sensitivity of $100 \%$ and specificity of $89 \%$; contrast-enhanced MRI combined with diffusion MRI achieved $96 \%$ specificity [61]. An important consideration is that since 2007, administration of gadolinium has been avoided in end-stage renal disease or dialysis patients due to increased risk of nephrogenic systemic fibrosis, limiting use [64].

\section{Emerging technology}

CEUS has been increasingly applied to differentiate small renal masses, due to its ability to detect slow and low flow in the microcirculation $[5,65,66]$. In a meta-analysis of 567 histologically confirmed RCC and 313 benign masses, the pooled sensitivity of CEUS was $88 \%(85-9095 \% \mathrm{CI})$ and specificity was $80 \%$ (75-85\% 95\% CI) [65]. A recent feasibility study has demonstrated the usefulness of magnetic resonance elastography (MRE), as part of a multiparametric MR imaging protocol, to characterise 21 indeterminate SRM. MRE viscoelastic profile may discriminate between oncocytomas and clear cell RCC, and further prospective studies are warranted [67]. The emerging concept that biomedical images contain 'hidden' information about the underlying tissue biology that can be revealed via quantitative image analysis, an approach known as radiomics, has prompted 
the application of automated image analysis tools in renal tumours [68]. Early retrospective data have suggested that texture analysis of CT images combined with machine learning could distinguish RCC subtypes with an AUC $>0.90$, warranting prospective investigation [69]. Molecular imaging with ${ }^{99 \mathrm{~m}}$ technetium-sestamibi single photon emission computed tomography/computed tomography $\left({ }^{99 \mathrm{~m}} \mathrm{Tc}-\mathrm{MIBI}\right.$ SPECT/CT) has also been used to differentiate oncocytomas and indolent hybrid oncocytic/chromophobe tumours from other more aggressive malignant small renal tumours. The former contain numerous and dense cellular mitochondria and therefore demonstrate "hot" radiotracer uptake relative to the ipsilateral renal parenchyma, whereas the latter appear "cold" [70, 71]. Sheikhbahaei et al. evaluated the diagnostic accuracy of standard pre-operative CT, MRI and ${ }^{99 \mathrm{~m}} \mathrm{Tc}-$ MIBI SPECT/CT in 48 patients with small renal masses undergoing partial or radical nephrectomy. The area under the receiver operator characteristic curve for the differentiation of benign from malignant masses was 0.60 for $\mathrm{CT}$ and MRI alone, increasing to 0.85 with the addition of ${ }^{99 \mathrm{~m}} \mathrm{Tc}$ MIBI SPECT/CT [71]. Quantitative techniques for image analysis may enable increased accuracy and use of ${ }^{99 \mathrm{~m}} \mathrm{Tc}-$ MIBI SPECT/CT in future [72].

\section{Staging}

Staging in renal cancer is important for therapeutic triage and to define prognosis. Five-year survival rate is $84 \%$ in patients with Stage I (localised) cancer compared to
5\% with Stage IV (metastatic) disease [73]. CT remains the first-line modality for staging of locoregional and suspected metastatic disease. Staging accuracy for CT is good with the general exception of early perinephric invasion and venous invasion. In one study of 100 pathologically proven cancers, CT correctly staged $91 \%$ of cancers [74]. The sensitivity and specificity of CT for perinephric extension, venous invasion, metastatic adenopathy and organ invasion was $46,78,83$ and $60 \%$, respectively, and 98, 96, 88 and $100 \%$, respectively. The low sensitivity for perinephric invasion in this study is likely influenced by the author's chosen definition, i.e. a $1 \mathrm{~cm}$ perinephric soft tissue mass, and by the use of older generation scanners. A more recent study has suggested that $9 \%$ of patients may be upstaged from T1 (organ-confined) to T3a (peri-nephric invasion) at pathology [75]. The limitation of using size for determining nodal status is well known. Up to $58 \%$ of patients with enlarged ( $>1 \mathrm{~cm}$ short axis) nodes on CT will not have metastases [76].

MR demonstrates a greater sensitivity for inferior vena cava involvement than $\mathrm{CT}$ and comparable performance for perinephric invasion, metastatic adenopathy and organ invasion, but is not performed routinely (Fig. 4) [77]. Positron emission tomography (PET)/CT with ${ }^{18} \mathrm{~F}$-fluorodeoxyglucose (FDG) as tracer has its limitations due to the renal excretion of FDG and thus high background activity within the kidney; however, studies have suggested comparable locoregional staging accuracy with CT alone with false negative rates of $4 \%[78,79]$.

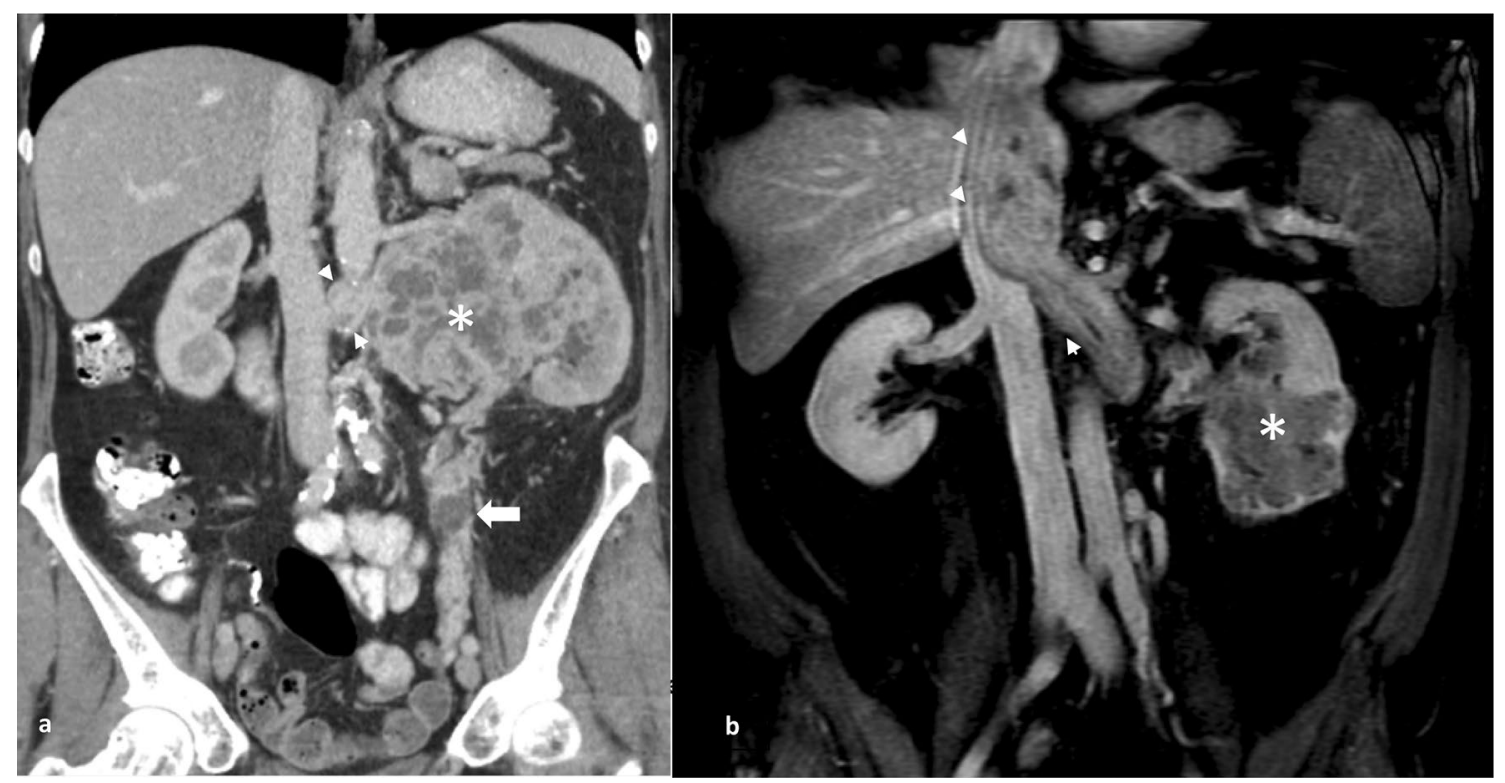

Fig. 4 Coronal portal venous phase CT depicting a large left lower pole renal tumour (star) with direct extension into the renal vein (arrowheads) and along the gonadal vein (filled arrow). Coronal fatsaturated T1 weighted MRI images following intravenous gadolinium in a different case demonstrate enhancing tumour thrombus within the left renal vein and extending into the infradiaphragmatic vena cava (stage T3b) 
For suspected osseous disease, bone scintigraphy (99Tcradioisotope scan) detects areas of increased osteoblastic activity that occurs as a compensatory mechanism after bone resorption [80]. Sensitivity and specificity of 94 and $86 \%$ have been reported [81]. False negatives have been reported with bone scintigraphy due to the lytic nature of metastases. The sensitivity for bone disease may be higher with ${ }^{18} \mathrm{~F}$-FDG $\mathrm{PET} / \mathrm{CT}$; however, PET/CT is not part of the standard care pathway [82]. MR is used routinely where there is clinical suspicion of spinal cord compression (Fig. 5). Whole body MR has been advocated for its higher sensitivity for the detection of bone metastases than scintigraphy, but this has not been investigated specifically in metastatic RCC; its limitations include the time taken to carry out an examination (typically, $60 \mathrm{~min}$ ) and limited access to scanners.

\section{Assessment of therapy response}

Percutaneous cryoablation or radiofrequency ablation of SRM is routinely performed in patients with multiple comorbidities or those wishing to preserve renal function [5-8]. However, response assessment following ablative therapy for localised RCC remains challenging, as reduction in tumour size, which is the mainstay of therapy assessment in other contexts, may not occur [12]. In fact, an increase in lesion size may be noted in the period immediately following successful ablative therapy and the pattern of enhancement may be a more reliable indicator of treatment success [83], although prediction of early recurrence remains a challenge. The hallmark of successful treatment is considered to be lack of enhancement in the treated tissue, whereas typically residual tumour or treatment failure is noted as a nodular or crescent-shaped enhancement on contrast-enhanced CT or MRI. Some studies suggest this may not be a reliable predictor, as discrepancies have been noted between enhancement on imaging and repeat biopsy results, although the accuracy of biopsy has also been called into question [84, 85]. Following radiofrequency ablation, long-term signs include a characteristic "bull's-eye" or "halo" sign appearance [86]. A gradual reduction in lesion size may occur, but this is much more common in cryoablation than radiofrequency ablation [87, 88]. Following cryoablation, tumours may demonstrate scar formation and on occasion an enhancing rim, which may persist for several months, and is due to hyperaemia and inflammation rather than recurrence [84]. In response to a lack of uniformity in the definition of local recurrence following ablative therapy, the International Working Group on Image-Guided Tumour Ablation (2005) established the following definition: presence of localised disease remaining in the kidney, as evidenced by tumour enhancement following the first ablation, or a visible increase in lesion size at the site of the previous ablation, with or without contrast enhancement [89]. This definition was later expanded to include "the failure of an
Fig. 5 Sagittal T1 weighted MRI (a) and CT (b) images of the thoracolumbar spine demonstrating metastatic infiltration at L4 and T12 with an associated pathological fracture and narrowing of the central vertebral canal

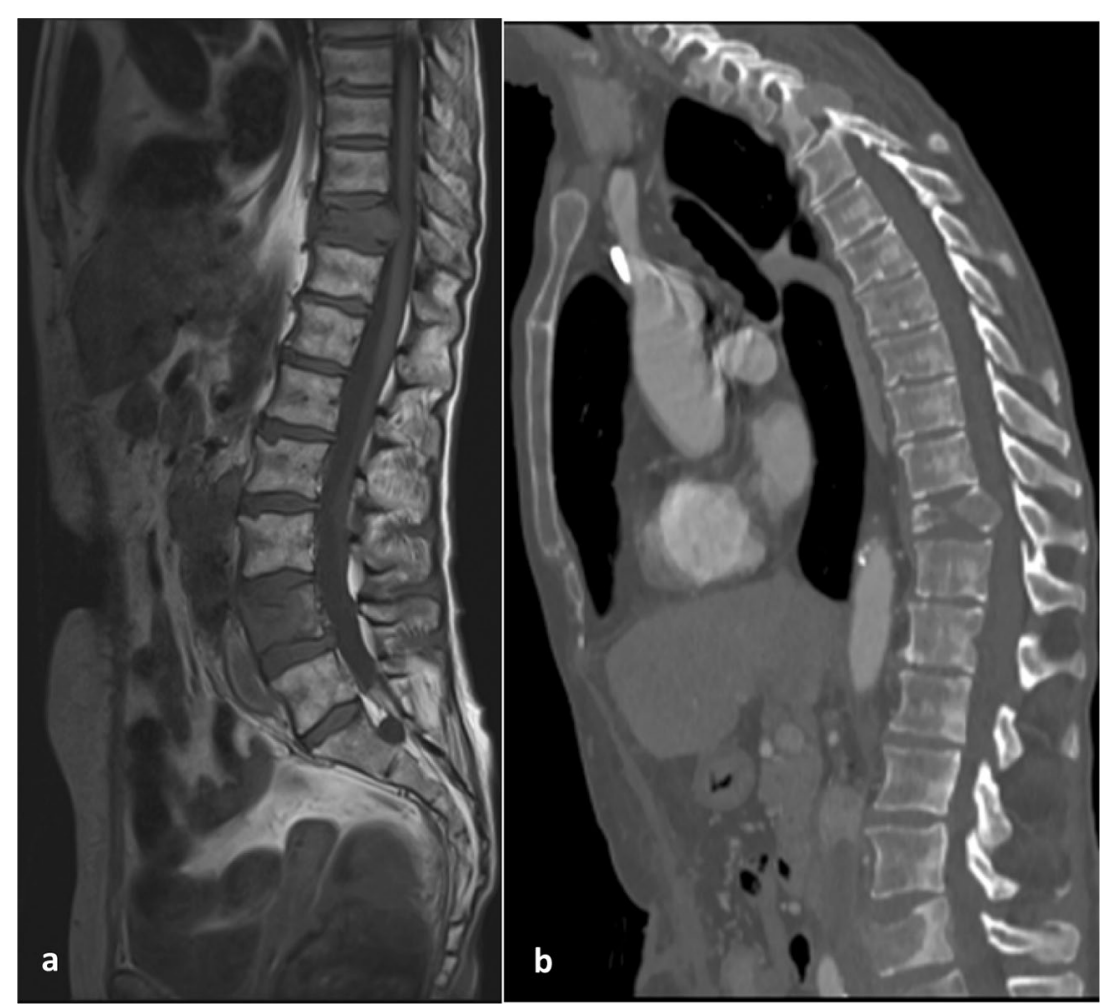


ablated lesion to regress in size over time, or the development of new satellite or port site soft tissue nodules [90, 91]."

In a series of over 600 patients treated with primary cryoablation or radiofrequency ablation, 63 patients experienced incomplete treatment (defined as residual or recurrent disease). $70 \%$ of incomplete treatments were detected within 3 months of therapy [92]. As such, AUA guidelines recommend follow-up CT or MRI with and without contrast at 3 and 6 months post-therapy, followed by annual imaging for 5 years [91]. Further research is required to establish the evidence base behind these surveillance protocols, whether they translate to a survival benefit and the associated cost to patients and society [93]. The Ablation of Renal Masses Outcomes Registry (ARMOR), which is actively recruiting patients (Clinicaltrials.gov identifier: NCT01888198) in the USA, may provide useful data in this domain. There is also a need to improve the detection of residual disease, particularly as serial biopsy may underestimate this. Further prospective study of the role of perfusion imaging in this context is warranted by early data. CEUS has emerged as a potential tool to monitor response following ablative therapy and prospective studies are currently underway (ClinicalTrials.gov Identifier: NCT01141816).

\section{Response to local ablative therapy}

Similarly, challenges remain in the imaging-based response assessment of patients with metastatic RCC. An accurate assessment of response to therapy is crucial to guide clinical decisions regarding continuation of treatment. Furthermore, imaging-based progression is routinely used as a surrogate marker for survival in clinical trials; therefore, the development of standardised and validated criteria is key. Reduction
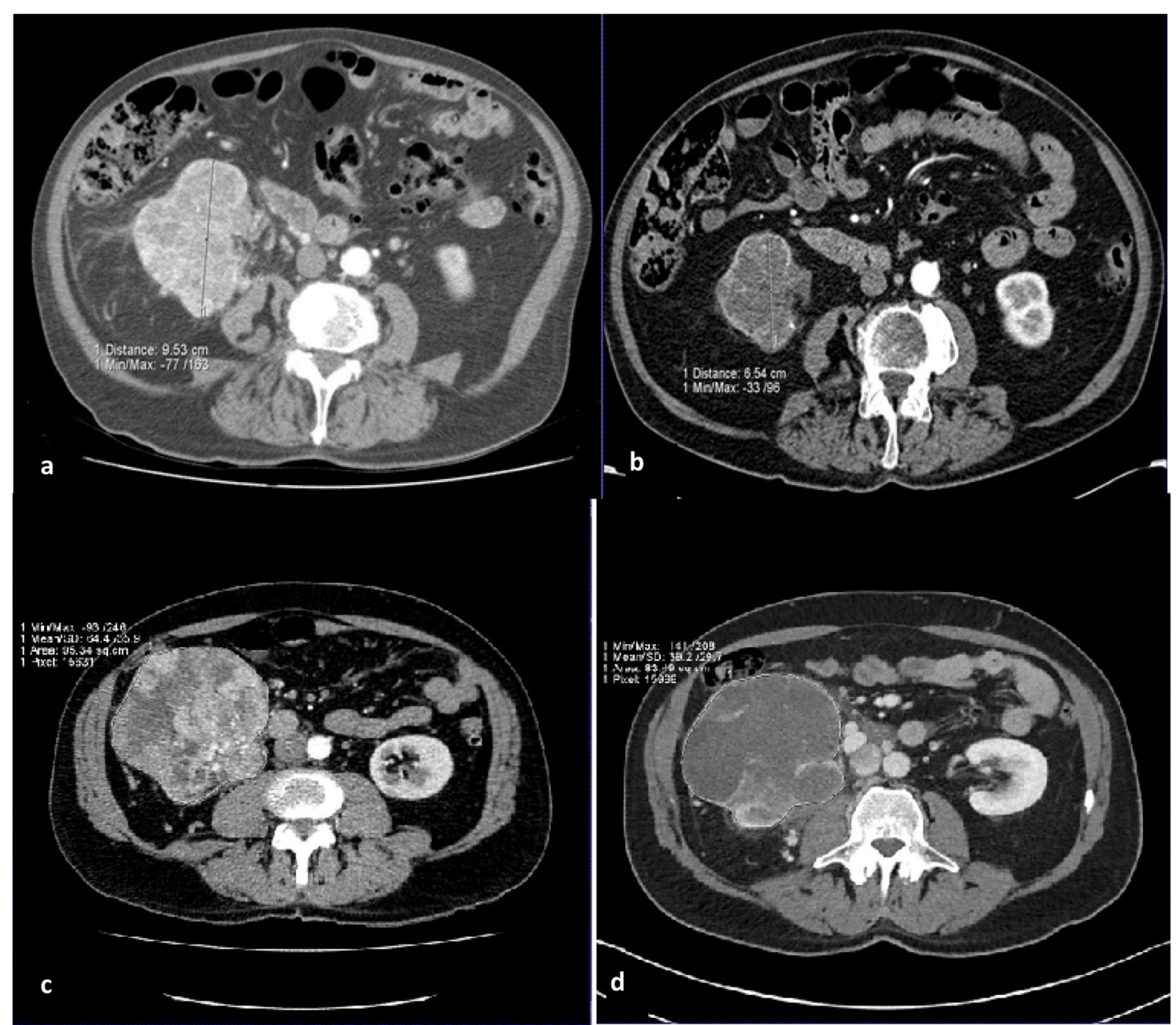

Fig. 6 Images (a) baseline and (b) depict the 31\% reduction in size of a right renal tumour over the course of 12 weeks targeted therapy, meeting criteria of partial response by RECIST v1.1. Conversely, images (c) at baseline and (d) in a different patient show that though

there is clear devascularisation of the right renal primary tumour on treatment with a reduction in central enhancement, there is insufficient reduction in size to amount to a partial response by RECIST $\mathrm{v}$ 1.1 assessment 
in tumour size remains at the core of therapy assessment with contrast-enhanced CT. For example, response assessment is performed by measuring the serial change in tumour size in up to five target lesions for Response Evaluation Criteria in Solid Tumors (RECIST) 1.1 (Fig. 6) [12]. However, in advanced RCC, response assessment based on size change has its limitations for both anti-angiogenic and immunotherapies. Anti-angiogenic therapies have a cytostatic rather than cytotoxic mechanism of action: tumour stabilisation occurs in the majority of cases and size reduction is often less pronounced and late occurring; therefore, RECIST criteria tend to underestimate response. Some tumours may even demonstrate an early increase in size due to necrosis. As a result, a number of alternative response criteria have been proposed to assess radiologic evidence of a reduction in tumour vascularity (Table 2). Such surrogate markers include: a reduction in attenuation, evidence of necrosis (new areas of nonenhancing soft tissue) and changes in the degree and pattern of enhancement [14-16, 94, 95].

Additionally, a number of emerging techniques have been investigated. CT texture analysis using an image processing algorithm to assess heterogeneity in tumour morphology has been proposed as a marker of response [96]. Functional imaging has been investigated, including dynamic contrast-enhanced (DCE) CT, DCE-MRI, DCE-ultrasound and PET [97]. DCE imaging follows the bio-distribution of a contrast agent injected intravenously and then absorbed into the tumour microcirculation, providing information on the tumour microenvironment and vascularity pre- and post-anti-angiogenic therapy [94]. A radiomic approach synthesising results from a combination of imaging modalities may play a role in future [97]. Recently, Crusz et al. noted that in a group of 27 patients with metastatic RCC receiving tyrosine kinase inhibitors, over $50 \%$ of individuals demonstrated heterogeneous responses to therapy (defined as lesions in at least two of the following three response categories: responding, progressing and stable), potentially reflecting molecular intra-tumoral heterogeneity [98]. This may have important implications for clinical decision making, such as the choice to continue therapy in individuals with heterogeneous responses.

Due to their targeted mechanism of action, eliciting an immune response, immunotherapies have been known to lead to "pseudoprogression" or "tumour flare," with consequent underestimation of the overall survival benefits using the traditional RECIST 1.1 criteria [18]. Partly because the pathophysiological mechanism underlying pseudoprogression is incompletely understood, differentiating this phenomenon from true progression represents an imaging diagnostic challenge with important clinical implications [99]. Four patterns of response to immunotherapy have been described: (1) an initial transient increase in target lesion size followed by durable response; (2) the development of new lesions followed by durable response in target lesions; (3) reduction in target lesion size from the outset; and (4) initially no change in target lesion size followed by a slow reduction in size [17]. To capture this response heterogeneity and variability, the 'Immune-Related Response Criteria' (irRC) were first developed, based on a bi-dimensional assessment of target lesion size (Table 3). In contrast to RECIST 1.1, the development of new lesions in irRC is not automatically considered as evidence of progression; rather, the size of the new lesion is added to the total tumour burden. Following irRC, a modified version of RECIST 1.1 for immunebased therapeutics (iRECIST) was proposed, returning to unidimensional assessment of lesions. The main novelty in iRECIST criteria is the differentiation between unconfirmed progressive disease (iUPD) and confirmed progressive disease (iCPD), to reflect the fact that iUPD may indeed represent pseudoprogression [100]. Most recently in 2018, the Immune-modified RECIST (imRECIST) criteria were published, once again utilising unidimensional measurements to improve reproducibility (by reducing measurement variability and error inherent in acquiring two dimensions per lesion). All these sets of criteria require prospective validation. Tumour response patterns may even vary between specific immunotherapy agents, and between tumour types: further response criteria modifications may be inevitable in the future [18].

\section{Response to therapy for metastatic disease}

Imaging plays a key role throughout the RCC patient pathway, from diagnosis and staging of the disease, to the assessment of response to therapy. Characterisation of incidentally detected small renal masses remains a diagnostic challenge due to the overlap in morphological and physiological characteristics of malignant and benign lesions. A multiparametric imaging approach is most likely to yield the highest diagnostic accuracy. CT remains an accurate imaging modality for staging renal cancer: its previously documented limitations in detecting early perinephric and venous extension warrant further investigation with state-of-the-art scanners. In this context, locoregional staging may be improved with state-of-theart MRI, including diffusion-weighted imaging. Accurate response assessment following therapy is key to guide management and inform patients about their prognosis and treatment. There is a need to improve the detection of residual disease following ablative therapy, and several clinical studies are currently underway in this field. In the era of targeted therapies and immunotherapy, size-based response assessment is limited: further development and validation of targeted imaging techniques and of response 


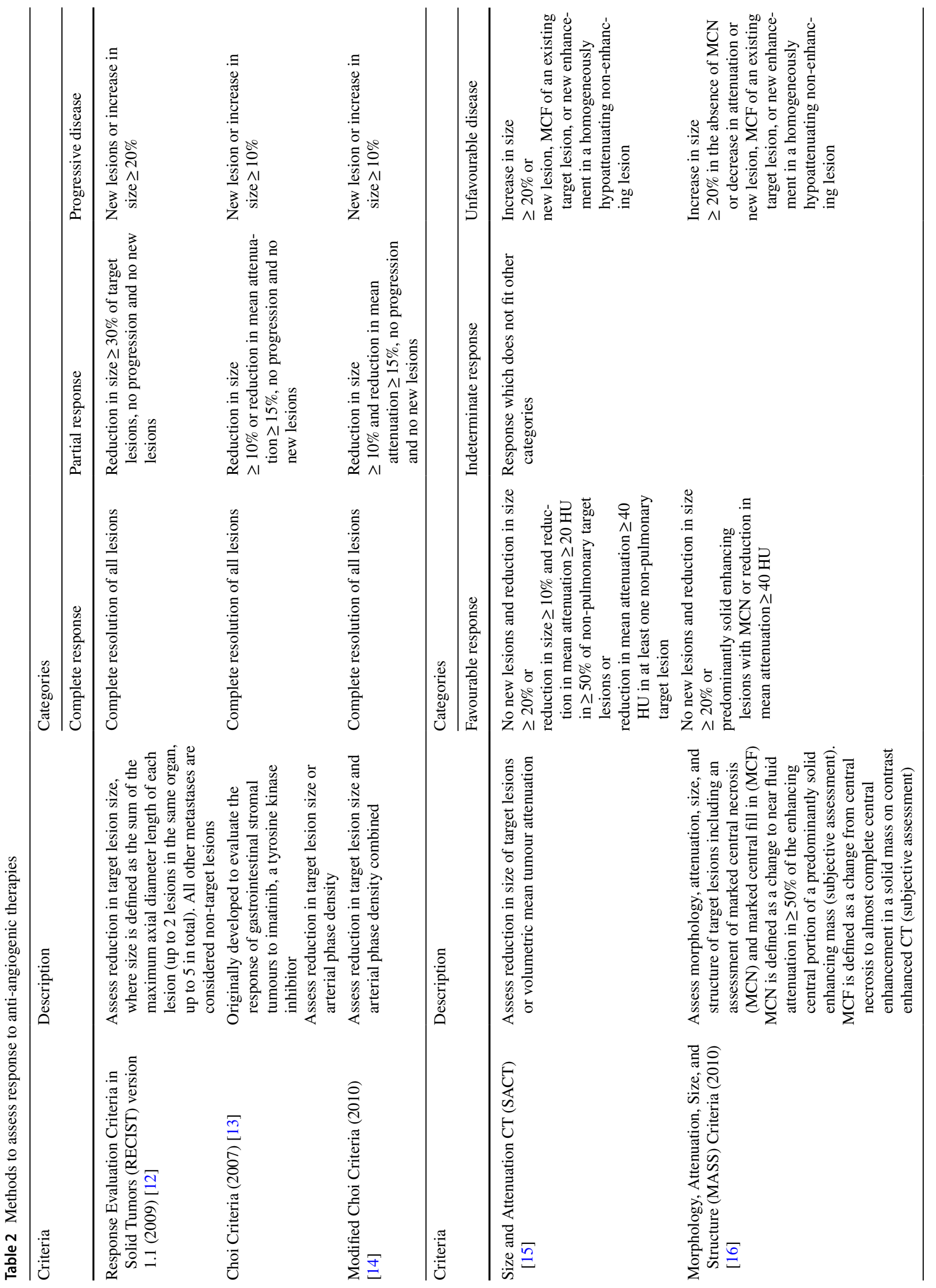




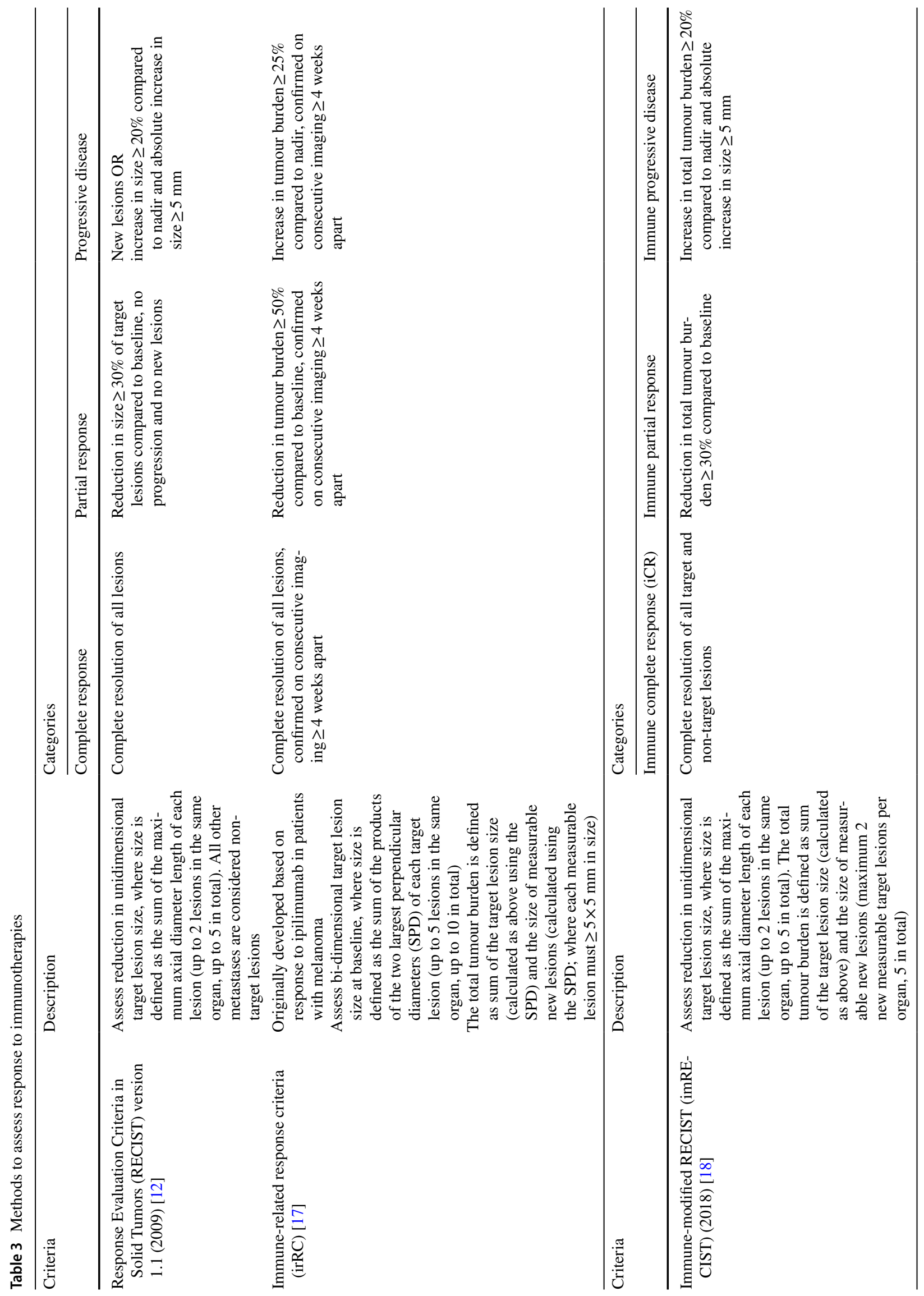


criteria that better reflect the effect of these agents are required for metastatic renal cell cancer.

Acknowledgements We would like to acknowledge the Urology Foundation, which kindly provided a research grant for SHR.

Author contributions SHR: Project development, data collection, data analysis, manuscript writing and editing. DP: project development, data collection, data analysis, manuscript writing and editing. CK-M: project development, data analysis, manuscript writing and editing. VG: project development, data analysis and manuscript editing.

\section{Compliance with ethical standards}

Conflict of interest The authors declare that they have no relevant conflict of interest.

Research involving human participants and/or animals The following manuscript is a review of existing data. Therefore, this article does not contain any studies with human participants or animals performed by any of the authors.

Informed consent For this type of study (review) formal consent is not required.

Open Access This article is distributed under the terms of the Creative Commons Attribution 4.0 International License (http://creativeco mmons.org/licenses/by/4.0/), which permits unrestricted use, distribution, and reproduction in any medium, provided you give appropriate credit to the original author(s) and the source, provide a link to the Creative Commons license, and indicate if changes were made.

\section{References}

1. Znaor A, Laversanne M, Bray F (2017) Less overdiagnosis of kidney cancer? An age-period-cohort analysis of incidence trends in 16 populations worldwide. Int J Cancer 141(5):925-932. https ://doi.org/10.1002/ijc.30799. Accessed 1 Mar 2018

2. UK CR Kidney cancer incidence statistics. http://www.cance rresearchuk.org/health-professional/cancer-statistics/statistics -by-cancer-type/kidney-cancer/incidence. Accessed 1 Mar 2018

3. Rossi SH, Klatte T, Usher-Smith J, Stewart GD (2018) Epidemiology and screening for renal cancer. World J Urol. https://doi. org/10.1007/s00345-018-2286-7

4. Heilbrun ME, Yu J, Smith KJ, Dechet CB, Zagoria RJ, Roberts MS (2012) The cost-effectiveness of immediate treatment, percutaneous biopsy and active surveillance for the diagnosis of the small solid renal mass: evidence from a Markov model. J Urol 187(1):39-43. https://doi.org/10.1016/j.juro.2011.09.055

5. Ljungberg B, Bensalah K, Canfield S, Dabestani S, Hofmann F, Hora M, Kuczyk MA, Lam T, Marconi L, Merseburger AS, Mulders P, Powles T, Staehler M, Volpe A, Bex A (2015) EAU guidelines on renal cell carcinoma: 2014 update. Eur Urol 67(5):913-924. https://doi.org/10.1016/j.eururo.2015.01.005

6. Krokidis ME, Orsi F, Katsanos K, Helmberger T, Adam A (2017) CIRSE guidelines on percutaneous ablation of small renal cell carcinoma. Cardiovasc Intervent Radiol 40(2):177-191. https:// doi.org/10.1007/s00270-016-1531-y

7. Campbell S, Uzzo RG, Allaf ME, Bass EB, Cadeddu JA, Chang A, Clark PE, Davis BJ, Derweesh IH, Giambarresi L, Gervais DA, Hu SL, Lane BR, Leibovich BC, Pierorazio PM (2017)
Renal mass and localized renal cancer: AUA guideline. J Urol 198(3):520-529. https://doi.org/10.1016/j.juro.2017.04.100

8. Escudier B, Porta C, Schmidinger M, Rioux-Leclercq N, Bex A, Khoo V, Gruenvald V, Horwich A, Committee EG (2016) Renal cell carcinoma: ESMO Clinical Practice Guidelines for diagnosis, treatment and follow-up. Ann Oncol 27(suppl 5):v58-v68. https://doi.org/10.1093/annonc/mdw328

9. Davis R, Jones JS, Barocas DA, Castle EP, Lang EK, Leveillee RJ, Messing EM, Miller SD, Peterson AC, Turk TM, Weitzel W, American Urological A (2012) Diagnosis, evaluation and follow-up of asymptomatic microhematuria (AMH) in adults: AUA guideline. J Urol 188(6 Suppl):2473-2481. https://doi. org/10.1016/j.juro.2012.09.078

10. Kassouf W, Aprikian A, Black P, Kulkarni G, Izawa J, Eapen L, Fairey A, So A, North S, Rendon R, Sridhar SS, Alam T, Brimo F, Blais N, Booth C, Chin J, Chung P, Drachenberg D, Fradet Y, Jewett M, Moore R, Morash C, Shayegan B, Gotto G, Fleshner N, Saad F, Siemens DR (2016) Recommendations for the improvement of bladder cancer quality of care in Canada: a consensus document reviewed and endorsed by Bladder Cancer Canada (BCC), Canadian Urologic Oncology Group (CUOG), and Canadian Urological Association (CUA). Can Urol Assoc J 10(1-2):E46-80. https://doi.org/10.5489/cuaj.3583

11. Shen LRRS, Beland MD et al (2014) American College of Radiologists Appropriateness Criteria: Hematuria 2014. https ://acsearch.acr.org/docs/69490/Narrative. Accessed March 2018

12. Eisenhauer EA, Therasse P, Bogaerts J, Schwartz LH, Sargent D, Ford R, Dancey J, Arbuck S, Gwyther S, Mooney M, Rubinstein L, Shankar L, Dodd L, Kaplan R, Lacombe D, Verweij J (2009) New response evaluation criteria in solid tumours: revised RECIST guideline (version 1.1). Eur J Cancer 45(2):228-247. https://doi.org/10.1016/j.ejca.2008.10.026

13. Choi H, Charnsangavej C, Faria SC, Macapinlac HA, Burgess MA, Patel SR, Chen LL, Podoloff DA, Benjamin RS (2007) Correlation of computed tomography and positron emission tomography in patients with metastatic gastrointestinal stromal tumor treated at a single institution with imatinib mesylate: proposal of new computed tomography response criteria. J Clin Oncol 25(13):1753-1759. https://doi.org/10.1200/ JCO.2006.07.3049

14. Nathan PD, Vinayan A, Stott D, Juttla J, Goh V (2010) CT response assessment combining reduction in both size and arterial phase density correlates with time to progression in metastatic renal cancer patients treated with targeted therapies. Cancer Biol Ther 9(1):15-19

15. Smith AD, Lieber ML, Shah SN (2010) Assessing tumor response and detecting recurrence in metastatic renal cell carcinoma on targeted therapy: importance of size and attenuation on contrast-enhanced CT. AJR Am J Roentgenol 194(1):157-165. https://doi.org/10.2214/ajr.09.2941

16. Smith AD, Shah SN, Rini BI, Lieber ML, Remer EM (2010) Morphology, Attenuation, Size, and Structure (MASS) criteria: assessing response and predicting clinical outcome in metastatic renal cell carcinoma on antiangiogenic targeted therapy. AJR Am J Roentgenol 194(6):1470-1478. https://doi.org/10.2214/ ajr.09.3456

17. Wolchok JD, Hoos A, O'Day S, Weber JS, Hamid O, Lebbe C, Maio M, Binder M, Bohnsack O, Nichol G, Humphrey R, Hodi FS (2009) Guidelines for the evaluation of immune therapy activity in solid tumors: immune-related response criteria. Clin Cancer Res 15(23):7412-7420. https://doi.org/10.1158/1078-0432. CCR-09-1624

18. Hodi FS, Ballinger M, Lyons B, Soria JC, Nishino M, Tabernero J, Powles T, Smith D, Hoos A, McKenna C, Beyer U, Rhee I, Fine G, Winslow N, Chen DS, Wolchok JD (2018) 
Immune-Modified Response Evaluation Criteria In Solid Tumors (imRECIST): refining guidelines to assess the clinical benefit of cancer immunotherapy. J Clin Oncol. https://doi.org/10.1200/ jco.2017.75.1644

19. Ficarra V, Prayer-Galetti T, Novella G, Bratti E, Maffei N, Dal Bianco M, Artibani W, Pagano F (2003) Incidental detection beyond pathological factors as prognostic predictor of renal cell carcinoma. Eur Urol 43(6):663-669

20. Patard JJ, Rodriguez A, Rioux-Leclercq N, Guille F, Lobel B (2002) Prognostic significance of the mode of detection in renal tumours. BJU Int 90(4):358-363

21. Khadra MH, Pickard RS, Charlton M, Powell PH, Neal DE (2000) A prospective analysis of 1,930 patients with hematuria to evaluate current diagnostic practice. J Urol 163(2):524-527

22. Edwards TJ, Dickinson AJ, Natale S, Gosling J, McGrath JS (2006) A prospective analysis of the diagnostic yield resulting from the attendance of 4020 patients at a protocol-driven haematuria clinic. BJU Int 97(2):301-305; discussion 305. https:// doi.org/10.1111/j.1464-410x.2006.05976.x

23. Linder BJ, Bass EJ, Mostafid H, Boorjian SA (2018) Guideline of guidelines: asymptomatic microscopic haematuria. BJU Int 121(2):176-183. https://doi.org/10.1111/bju.14016

24. Halpern JA, Chughtai B, Ghomrawi H (2017) Cost-effectiveness of common diagnostic approaches for evaluation of asymptomatic microscopic hematuria. JAMA Intern Med 177(6):800807. https://doi.org/10.1001/jamainternmed.2017.0739

25. Amdahl J, Diaz J, Sharma A, Park J, Chandiwana D, Delea TE (2017) Cost-effectiveness of pazopanib versus sunitinib for metastatic renal cell carcinoma in the United Kingdom. PLoS ONE 12(6):e0175920. https://doi.org/10.1371/journal.pone.0175920

26. Warshauer DM, McCarthy SM, Street L, Bookbinder MJ, Glickman MG, Richter J, Hammers L, Taylor C, Rosenfield AT (1988) Detection of renal masses: sensitivities and specificities of excretory urography/linear tomography, US, and CT. Radiology 169(2):363-365. https://doi.org/10.1148/radiology.169.2.3051112

27. O'Connor OJ, McSweeney SE, Maher MM (2008) Imaging of hematuria. Radiol Clin N Am 46(1):113-132, vii. https://doi. org/10.1016/j.rcl.2008.01.007

28. Cowan NC (2012) CT urography for hematuria. Nat Rev Urol 9(4):218-226. https://doi.org/10.1038/nrurol.2012.32

29. Gray Sears CL, Ward JF, Sears ST, Puckett MF, Kane CJ, Amling CL (2002) Prospective comparison of computerized tomography and excretory urography in the initial evaluation of asymptomatic microhematuria. J Urol 168(6):2457-2460. https://doi. org/10.1097/01.ju.0000036541.52816.98

30. Silverman SG, Leyendecker JR, Amis ES Jr (2009) What is the current role of CT urography and MR urography in the evaluation of the urinary tract? Radiology 250(2):309-323. https://doi. org/10.1148/radiol.2502080534

31. Rabjerg M, Mikkelsen MN, Walter S, Marcussen N (2014) Incidental renal neoplasms: is there a need for routine screening? A Danish single-center epidemiological study. APMIS 122(8):708714. https://doi.org/10.1111/apm.12282

32. Welch HG, Skinner JS, Schroeck FR, Zhou W, Black WC (2018) Regional variation of computed tomographic imaging in the United States and the risk of nephrectomy. JAMA Intern Med 178(2):221-227. https://doi.org/10.1001/jamaintern med.2017.7508

33. O'Connor SD, Pickhardt PJ, Kim DH, Oliva MR, Silverman SG (2011) Incidental finding of renal masses at unenhanced CT: prevalence and analysis of features for guiding management. AJR Am J Roentgenol 197(1):139-145. https://doi.org/10.2214/ ajr. 10.5920

34. Bosniak MA (1986) The current radiological approach to renal cysts. Radiology 158(1):1-10. https://doi.org/10.1148/radio logy.158.1.3510019
35. Sevcenco S, Spick C, Helbich TH, Heinz G, Shariat SF, Klingler HC, Rauchenwald M, Baltzer PA (2017) Malignancy rates and diagnostic performance of the Bosniak classification for the diagnosis of cystic renal lesions in computed tomography - a systematic review and meta-analysis. Eur Radiol 27(6):2239-2247. https://doi.org/10.1007/s00330-016-4631-9

36. Birnbaum BA, Hindman N, Lee J, Babb JS (2007) Renal cyst pseudoenhancement: influence of multidetector CT reconstruction algorithm and scanner type in phantom model. Radiology 244(3):767-775. https://doi.org/10.1148/radiol.2443061537

37. Schoots IG, Zaccai K, Hunink MG, Verhagen P (2017) Bosniak classification for complex renal cysts reevaluated: a systematic review. J Urol 198(1):12-21. https://doi.org/10.1016/j. juro.2016.09.160

38. Pitra T, Pivovarcikova K, Tupy R, Alaghehbandan R, Barakova T, Travnicek I, Prochazkova K, Klatte T, Chlosta P, Hes O, Hora $M$ (2018) Magnetic resonance imaging as an adjunct diagnostic tool in computed tomography defined Bosniak IIF-III renal cysts: a multicenter study. World J Urol. https://doi.org/10.1007/s0034 5-018-2176-z

39. Bosniak MA (2012) The Bosniak renal cyst classification: 25 years later. Radiology 262(3):781-785. https://doi. org/10.1148/radiol.11111595

40. Ascenti G, Mazziotti S, Zimbaro G, Settineri N, Magno C, Melloni D, Caruso R, Scribano E (2007) Complex cystic renal masses: characterization with contrast-enhanced US. Radiology 243(1):158-165. https://doi.org/10.1148/radiol.2431051924

41. Quaia E, Bertolotto M, Cioffi V, Rossi A, Baratella E, Pizzolato R, Cov MA (2008) Comparison of contrast-enhanced sonography with unenhanced sonography and contrast-enhanced CT in the diagnosis of malignancy in complex cystic renal masses. AJR Am J Roentgenol 191(4):1239-1249. https://doi.org/10.2214/ AJR.07.3546

42. Defortescu G, Cornu JN, Bejar S, Giwerc A, Gobet F, Werquin C, Pfister C, Nouhaud FX (2017) Diagnostic performance of contrast-enhanced ultrasonography and magnetic resonance imaging for the assessment of complex renal cysts: a prospective study. Int J Urol 24(3):184-189. https://doi.org/10.1111/iju.13289

43. Johnson DC, Vukina J, Smith AB, Meyer AM, Wheeler SB, Kuo TM, Tan HJ, Woods ME, Raynor MC, Wallen EM, Pruthi RS, Nielsen ME (2015) Preoperatively misclassified, surgically removed benign renal masses: a systematic review of surgical series and United States population level burden estimate. J Urol 193(1):30-35. https://doi.org/10.1016/j.juro.2014.07.102

44. Schlomer B, Figenshau RS, Yan Y, Venkatesh R, Bhayani SB (2006) Pathological features of renal neoplasms classified by size and symptomatology. J Urol 176(4 Pt 1):1317-1320; discussion 1320. https://doi.org/10.1016/j.juro.2006.06.005

45. Akdogan B, Gudeloglu A, Inci K, Gunay LM, Koni A, Ozen $H$ (2012) Prevalence and predictors of benign lesions in renal masses smaller than $7 \mathrm{~cm}$ presumed to be renal cell carcinoma. Clin Genitourin Cancer 10(2):121-125. https://doi.org/10.1016/j. clgc.2012.01.005

46. Golan S, Eggener S, Subotic S, Barret E, Cormio L, Naito S, Tefekli A, Pilar Laguna Pes M (2016) Prediction of renal mass aggressiveness using clinical and radiographic features: a global, multicentre prospective study. BJU Int 117(6):914-922. https:// doi.org/10.1111/bju.13331

47. Bauman TM, Potretzke AM, Wright AJ, Knight BA, Vetter JM, Figenshau RS (2017) Partial nephrectomy for presumed renalcell carcinoma: incidence, predictors, and perioperative outcomes of benign lesions. J Endourol 31(4):412-417. https://doi. org/10.1089/end.2016.0667

48. Secin FP, Castillo OA, Rozanec JJ, Featherston M, Holst P, Milfont JC, Garcia Marchinena P, Jurado Navarro A, Autran A, Rovegno AR, Faba OR, Palou J, Teixeira Dubeux V, Nunez 
Bragayrac L, Sotelo R, Zequi S, Guimaraes GC, Alvarez-Maestro M, Martinez-Pineiro L, Villoldo G, Villaronga A, Abreu Clavijo D, Decia R, Frota R, Vidal-Mora I, Finkelstein D, Monzo Gardiner JI, Schatloff O, Hernandez-Porras A, Santaella-Torres F, Quesada ET, Sanchez-Salas R, Davila H, Mavric HV (2017) American Confederation of Urology (CAU) experience in minimally invasive partial nephrectomy. World J Urol 35(1):57-65. https://doi.org/10.1007/s00345-016-1837-z

49. Millet I, Doyon FC, Hoa D, Thuret R, Merigeaud S, Serre I, Taourel P (2011) Characterization of small solid renal lesions: can benign and malignant tumors be differentiated with CT? AJR Am J Roentgenol 197(4):887-896. https://doi.org/10.2214/ AJR.10.6276

50. Kim JK, Park SY, Shon JH, Cho KS (2004) Angiomyolipoma with minimal fat: differentiation from renal cell carcinoma at biphasic helical CT. Radiology 230(3):677-684. https://doi. org/10.1148/radiol.2303030003

51. Hafron J, Fogarty JD, Hoenig DM, Li M, Berkenblit R, Ghavamian R (2005) Imaging characteristics of minimal fat renal angiomyolipoma with histologic correlations. Urology 66(6):11551159. https://doi.org/10.1016/j.urology.2005.06.119

52. Schieda N, Hodgdon T, El-Khodary M, Flood TA, McInnes MD (2014) Unenhanced CT for the diagnosis of minimal-fat renal angiomyolipoma. AJR Am J Roentgenol 203(6):1236-1241. https://doi.org/10.2214/AJR.14.12630

53. Woo S, Suh CH, Cho JY, Kim SY, Kim SH (2017) Diagnostic performance of CT for diagnosis of fat-poor angiomyolipoma in patients with renal masses: a systematic review and metaanalysis. AJR Am J Roentgenol 209(5):W297-W307. https:// doi.org/10.2214/AJR.17.18184

54. Neves JB, Withington J, Fowler S, Patki P, Barod R, Mumtaz F, O’Brien T, Aitchison M, Bex A, Tran MGB, British Association of Urological Surgeons (2018) Contemporary surgical management of renal oncocytoma: a nation's outcome. BJU Int. https:// doi.org/10.1111/bju.14159

55. Patel HD, Druskin SC, Rowe SP, Pierorazio PM, Gorin MA, Allaf ME (2017) Surgical histopathology for suspected oncocytoma on renal mass biopsy: a systematic review and meta-analysis. BJU Int 119(5):661-666. https://doi.org/10.1111/bju.13763

56. Galia M, Albano D, Bruno A, Agrusa A, Romano G, Di Buono G, Agnello F, Salvaggio G, La Grutta L, Midiri M, Lagalla $\mathrm{R}$ (2017) Imaging features of solid renal masses. Br J Radiol 90(1077):20170077. https://doi.org/10.1259/bjr.20170077

57. Kim JI, Cho JY, Moon KC, Lee HJ, Kim SH (2009) Segmental enhancement inversion at biphasic multidetector CT: characteristic finding of small renal oncocytoma. Radiology 252(2):441448. https://doi.org/10.1148/radiol.2522081180

58. Cornelis F, Lasserre AS, Tourdias T, Deminiere C, Ferriere JM, Le Bras Y, Grenier N (2013) Combined late gadoliniumenhanced and double-echo chemical-shift MRI help to differentiate renal oncocytomas with high central T2 signal intensity from renal cell carcinomas. AJR Am J Roentgenol 200(4):830-838. https://doi.org/10.2214/AJR.12.9122

59. Schieda N, McInnes MD, Cao L (2014) Diagnostic accuracy of segmental enhancement inversion for diagnosis of renal oncocytoma at biphasic contrast enhanced CT: systematic review. Eur Radiol 24(6):1421-1429. https://doi.org/10.1007/s0033 0-014-3147-4

60. Young JR, Margolis D, Sauk S, Pantuck AJ, Sayre J, Raman SS (2013) Clear cell renal cell carcinoma: discrimination from other renal cell carcinoma subtypes and oncocytoma at multiphasic multidetector CT. Radiology 267(2):444-453. https:// doi.org/10.1148/radiol.13112617

61. Taouli B, Thakur RK, Mannelli L, Babb JS, Kim S, Hecht EM, Lee VS, Israel GM (2009) Renal lesions: characterization with diffusion-weighted imaging versus contrast-enhanced MR imaging. Radiology 251(2):398-407. https://doi.org/10.1148/ radiol.2512080880

62. Vargas HA, Chaim J, Lefkowitz RA, Lakhman Y, Zheng J, Moskowitz CS, Sohn MJ, Schwartz LH, Russo P, Akin O (2012) Renal cortical tumors: use of multiphasic contrast-enhanced MR imaging to differentiate benign and malignant histologic subtypes. Radiology 264(3):779-788. https://doi.org/10.1148/radio 1.12110746

63. Galmiche C, Bernhard JC, Yacoub M, Ravaud A, Grenier N, Cornelis F (2017) Is multiparametric MRI useful for differentiating oncocytomas from chromophobe renal cell carcinomas? AJR Am J Roentgenol 208(2):343-350. https://doi. org/10.2214/AJR.16.16832

64. Perazella MA, Rodby RA (2007) Gadolinium use in patients with kidney disease: a cause for concern. Semin Dial 20(3):179-185. https://doi.org/10.1111/j.1525139X.2007.00269.x

65. Wang C, Yu C, Yang F, Yang G (2014) Diagnostic accuracy of contrast-enhanced ultrasound for renal cell carcinoma: a metaanalysis. Tumour Biol 35(7):6343-6350. https://doi.org/10.1007/ s13277-014-1815-2

66. Tenant SC, Gutteridge CM (2016) The clinical use of contrastenhanced ultrasound in the kidney. Ultrasound 24(2):94-103. https://doi.org/10.1177/1742271X15627185

67. Prezzi D, Neji R, Kelly-Morland C, Verma H, O’Brien T, Challacombe B, Fernando A, Chandra A, Sinkus R, Goh V (2018) Characterization of small renal tumors with magnetic resonance elastography: a feasibility study. Invest Radiol. https://doi. org/10.1097/RLI.0000000000000449

68. Lambin P, Leijenaar RTH, Deist TM, Peerlings J, de Jong EEC, van Timmeren J, Sanduleanu S, Larue R, Even AJG, Jochems A, van Wijk Y, Woodruff H, van Soest J, Lustberg T, Roelofs E, van Elmpt W, Dekker A, Mottaghy FM, Wildberger JE, Walsh S (2017) Radiomics: the bridge between medical imaging and personalized medicine. Nat Rev Clin Oncol 14(12):749-762. https ://doi.org/10.1038/nrclinonc.2017.141

69. Yu H, Scalera J, Khalid M, Touret AS, Bloch N, Li B, Qureshi MM, Soto JA, Anderson SW (2017) Texture analysis as a radiomic marker for differentiating renal tumors. Abdom Radiol. https://doi.org/10.1007/s00261-017-1144-1

70. Gorin MA, Rowe SP, Baras AS, Solnes LB, Ball MW, Pierorazio PM, Pavlovich CP, Epstein JI, Javadi MS, Allaf ME (2016) Prospective evaluation of $(99 \mathrm{~m}) \mathrm{Tc}$-sestamibi SPECT/CT for the diagnosis of renal oncocytomas and hybrid oncocytic/chromophobe tumors. Eur Urol 69(3):413-416. https://doi.org/10.1016/j. eururo.2015.08.056

71. Sheikhbahaei S, Jones CS, Porter KK, Rowe SP, Gorin MA, Baras AS, Pierorazio PM, Ball MW, Higuchi T, Johnson PT, Solnes LB, Epstein JI, Allaf ME, Javadi MS (2017) Defining the added value of $99 \mathrm{mTc}$-MIBI SPECT/CT to conventional cross-sectional imaging in the characterization of enhancing solid renal masses. Clin Nucl Med 42(4):e188-e193. https://doi. org/10.1097/RLU.0000000000001534

72. Jones KM, Solnes LB, Rowe SP, Gorin MA, Sheikhbahaei S, Fung G, Frey EC, Allaf ME, Du Y, Javadi MS (2018) Use of quantitative SPECT/CT reconstruction in $(99 \mathrm{~m}) \mathrm{Tc}$-sestamibi imaging of patients with renal masses. Ann Nucl Med 32(2):8793. https://doi.org/10.1007/s12149-017-1222-z

73. Five-Year Relative Survival by Stage, Adults (Aged 15-99 Years), Former Anglia Cancer Network, 2002-2006 (2014) Cancer Research UK. http://www.cancerresearchuk.org/health-profe ssional/cancer-statistics/statistics-by-cancer-type/kidney-cance r/survival\#heading-Three. Accessed 26 July 2016

74. Johnson CD, Dunnick NR, Cohan RH, Illescas FF (1987) Renal adenocarcinoma: CT staging of 100 tumors. AJR Am J Roentgenol 148(1):59-63. https://doi.org/10.2214/ajr.148.1.59 
75. Nayak JG, Patel P, Saarela O, Liu Z, Kapoor A, Finelli A, Tanguay S, Rendon R, Moore R, Black PC, Lacombe L, Breau RH, Kawakami J, Drachenberg DE (2016) Pathological upstaging of clinical T1 to pathological T3a renal cell carcinoma: a multiinstitutional analysis of short-term outcomes. Urology 94:154160. https://doi.org/10.1016/j.urology.2016.03.029

76. Studer UE, Scherz S, Scheidegger J, Kraft R, Sonntag R, Ackermann D, Zingg EJ (1990) Enlargement of regional lymph nodes in renal cell carcinoma is often not due to metastases. J Urol 144(2 Pt 1):243-245

77. Semelka RC, Shoenut JP, Magro CM, Kroeker MA, MacMahon R, Greenberg HM (1993) Renal cancer staging: comparison of contrast-enhanced CT and gadolinium-enhanced fat-suppressed spin-echo and gradient-echo MR imaging. J Magn Reson Imaging 3(4):597-602

78. Goldberg MA, Mayo-Smith WW, Papanicolaou N, Fischman AJ, Lee MJ (1997) FDG PET characterization of renal masses: preliminary experience. Clin Radiol 52(7):510-515

79. Ramdave S, Thomas GW, Berlangieri SU, Bolton DM, Davis I, Danguy HT, Macgregor D, Scott AM (2001) Clinical role of F-18 fluorodeoxyglucose positron emission tomography for detection and management of renal cell carcinoma. J Urol 166(3):825-830

80. Shvarts O, Lam JS, Kim HL, Han KR, Figlin R, Belldegrun A (2004) Eastern Cooperative Oncology Group performance status predicts bone metastasis in patients presenting with renal cell carcinoma: implication for preoperative bone scans. J Urol 172(3):867-870. https://doi.org/10.1097/01.ju.0000135803 $.91207 . b 0$

81. Koga S, Tsuda S, Nishikido M, Ogawa Y, Hayashi K, Hayashi T, Kanetake H (2001) The diagnostic value of bone scan in patients with renal cell carcinoma. J Urol 166(6):2126-2128

82. Wu HC, Yen RF, Shen YY, Kao CH, Lin CC, Lee CC (2002) Comparing whole body $18 \mathrm{~F}$-2-deoxyglucose positron emission tomography and technetium-99m methylene diphosphate bone scan to detect bone metastases in patients with renal cell carcinomas-a preliminary report. J Cancer Res Clin Oncol 128(9):503-506. https://doi.org/10.1007/s00432-002-0370-1

83. Kawamoto S, Permpongkosol S, Bluemke DA, Fishman EK, Solomon SB (2007) Sequential changes after radiofrequency ablation and cryoablation of renal neoplasms: role of CT and MR imaging. Radiographics 27(2):343-355. https://doi.org/10.1148/ rg.272065119

84. Stein AJ, Mayes JM, Mouraviev V, Chen VH, Nelson RC, Polascik TJ (2008) Persistent contrast enhancement several months after laparoscopic cryoablation of the small renal mass may not indicate recurrent tumor. J Endourol 22(11):2433-2439. https:// doi.org/10.1089/end.2008.0261

85. Weight CJ, Kaouk JH, Hegarty NJ, Remer EM, O’Malley CM, Lane BR, Gill IS, Novick AC (2008) Correlation of radiographic imaging and histopathology following cryoablation and radio frequency ablation for renal tumors. J Urol 179(4):1277-1281; discussion 1281-1273. https://doi.org/10.1016/j.juro.2007.11.075

86. Iannuccilli JD, Grand DJ, Dupuy DE, Mayo-Smith WW (2014) Percutaneous ablation for small renal masses-imaging follow-up. Semin Intervent Radiol 31(1):50-63. https://doi. org/10.1055/s-0033-1363843

87. Ganguli S, Brennan DD, Faintuch S, Rayan ME, Goldberg SN (2008) Immediate renal tumor involution after radiofrequency thermal ablation. J Vasc Interv Radiol 19(3):412-418. https:// doi.org/10.1016/j.jvir.2007.10.024

88. Gill IS, Remer EM, Hasan WA, Strzempkowski B, Spaliviero M, Steinberg AP, Kaouk JH, Desai MM, Novick AC (2005) Renal cryoablation: outcome at 3 years. J Urol 173(6):1903-1907. https ://doi.org/10.1097/01.ju.0000158154.28845.c9

89. Goldberg SN, Grassi CJ, Cardella JF, Charboneau JW, Dodd GD, 3rd, Dupuy DE, Gervais D, Gillams AR, Kane RA, Lee FT, Jr.,
Livraghi T, McGahan J, Phillips DA, Rhim H, Silverman SG, Society of Interventional Radiology Technology Assessment C, International Working Group on Image-Guided Tumor A (2005) Image-guided tumor ablation: standardization of terminology and reporting criteria. Radiology 235(3):728-739. https://doi. org/10.1148/radiol.2353042205

90. Ahmed M, Solbiati L, Brace CL, Breen DJ, Callstrom MR, Charboneau JW, Chen MH, Choi BI, de Baere T, Dodd GD 3rd, Dupuy DE, Gervais DA, Gianfelice D, Gillams AR, Lee FT Jr, Leen E, Lencioni R, Littrup PJ, Livraghi T, Lu DS, McGahan JP, Meloni MF, Nikolic B, Pereira PL, Liang P, Rhim H, Rose SC, Salem R, Sofocleous CT, Solomon SB, Soulen MC, Tanaka M, Vogl TJ, Wood BJ, Goldberg SN, International Working Group on Image-guided Tumor A, Interventional Oncology Sans Frontieres Expert P, Technology Assessment Committee of the Society of Interventional R, Standard of Practice Committee of the C, Interventional Radiological Society of E (2014) Image-guided tumor ablation: standardization of terminology and reporting criteria—a 10-year update. Radiology 273(1):241-260. https:// doi.org/10.1148/radiol.14132958

91. Donat SM, Diaz M, Bishoff JT, Coleman JA, Dahm P, Derweesh IH, Herrell SD 3rd, Hilton S, Jonasch E, Lin DW, Reuter VE, Chang SS (2013) Follow-up for clinically localized renal neoplasms: AUA guideline. J Urol 190(2):407-416. https://doi. org/10.1016/j.juro.2013.04.121

92. Matin SF, Ahrar K, Cadeddu JA, Gervais DA, McGovern FJ, Zagoria RJ, Uzzo RG, Haaga J, Resnick MI, Kaouk J, Gill IS (2006) Residual and recurrent disease following renal energy ablative therapy: a multi-institutional study. J Urol 176(5):19731977. https://doi.org/10.1016/j.juro.2006.07.016

93. Klatte T, Kroeger N, Zimmermann U, Burchardt M, Belldegrun AS, Pantuck AJ (2014) The contemporary role of ablative treatment approaches in the management of renal cell carcinoma (RCC): focus on radiofrequency ablation (RFA), high-intensity focused ultrasound (HIFU), and cryoablation. World J Urol 32(3):597-605. https://doi.org/10.1007/s00345-014-1284-7

94. Bex A, Fournier L, Lassau N, Mulders P, Nathan P, Oyen WJ, Powles T (2014) Assessing the response to targeted therapies in renal cell carcinoma: technical insights and practical considerations. Eur Urol 65(4):766-777. https://doi.org/10.1016/j.eurur o.2013.11.031

95. Sirous R, Henegan JC, Zhang X, Howard CM, Souza F, Smith AD (2016) Metastatic renal cell carcinoma imaging evaluation in the era of anti-angiogenic therapies. Abdom Radiol 41(6):10861099. https://doi.org/10.1007/s00261-016-0742-7

96. Goh V, Ganeshan B, Nathan P, Juttla JK, Vinayan A, Miles KA (2011) Assessment of response to tyrosine kinase inhibitors in metastatic renal cell cancer: $\mathrm{CT}$ texture as a predictive biomarker. Radiology 261(1):165-171. https://doi.org/10.1148/radiol.11110 264

97. Hudson JM, Bailey C, Atri M, Stanisz G, Milot L, Williams R, Kiss A, Burns PN, Bjarnason GA (2018) The prognostic and predictive value of vascular response parameters measured by dynamic contrast-enhanced-CT, -MRI and -US in patients with metastatic renal cell carcinoma receiving sunitinib. Eur Radiol. https://doi.org/10.1007/s00330-017-5220-2

98. Crusz SM, Tang YZ, Sarker SJ, Prevoo W, Kiyani I, Beltran L, Peters J, Sahdev A, Bex A, Powles T, Gerlinger M (2016) Heterogeneous response and progression patterns reveal phenotypic heterogeneity of tyrosine kinase inhibitor response in metastatic renal cell carcinoma. BMC Med 14(1):185. https:// doi.org/10.1186/s12916-016-0729-9

99. Nishino M, Jagannathan JP, Krajewski KM, O'Regan K, Hatabu H, Shapiro G, Ramaiya NH (2012) Personalized tumor response assessment in the era of molecular medicine: cancer-specific and therapy-specific response criteria to complement pitfalls of 
RECIST. AJR Am J Roentgenol 198(4):737-745. https://doi. org/10.2214/ajr.11.7483

100. Seymour L, Bogaerts J, Perrone A, Ford R, Schwartz LH, Mandrekar S, Lin NU, Litiere S, Dancey J, Chen A, Hodi FS, Therasse P, Hoekstra OS, Shankar LK, Wolchok JD, Ballinger M, Caramella C, de Vries EG, RECIST Working Group (2017) iRECIST: guidelines for response criteria for use in trials testing immunotherapeutics. Lancet Oncol 18(3):e143-e152. https://doi. org/10.1016/S1470-2045(17)30074-8

101. Jamis-Dow CA, Choyke PL, Jennings SB, Linehan WM, Thakore KN, Walther MM (1996) Small $(<$ or $=3-\mathrm{cm})$ renal masses: detection with CT versus US and pathologic correlation. Radiology 198(3):785-788. https://doi.org/10.1148/radio logy.198.3.8628872 